\title{
INVENTION AND COMMEMORATION IN FOURTEENTH-CENTURY ENGLAND: A Monumental “Family Tree” at the Collegiate Church of St. Martin, LOWTHORPE
}

A striking monument is housed in the remote and semi-ruined church of St. Martin at Lowthorpe (Yorkshire, E.R.). Although the tomb is very worn from decades of exposure in the roofless chancel, it is still possible to discern its remarkable programme. ${ }^{1}$ A single block of magnesian limestone is carved with the life-size effigies of a man and woman (Fig. 1). The couple lies side-by-side with heads tilted towards one another; their bodies are concealed under a rippling cloth, evoking the

The research for this paper was funded by the Arts and Humanities Research Council and the Henry Moore Foundation. John Lowden, David Park and Sophie Oosterwijk offered invaluable advice and comments during the initial stages of writing. I would also like to thank Philip Reynolds for introducing me to the arboreal imagery of William of Auvergne. Last, but by no means least, I am extremely grateful to Linda Safran, Adam S. Cohen and the anonymous readers of Gesta for their insightful comments, which played a critical role in shaping this article into its present form. ${ }^{1}$ The earliest photographs I have found of the tomb in its current position are in the Conway Library, Courtauld Institute, and are undated. The chancel was abandoned in 1777; the memorial was almost certainly among the "curious monuments" present in the "desecrated" chancel in 1831. It was probably moved when the nave was rebuilt in 1859 (Nikolaus Pevsner and David Neave, Yorkshire: York and the East Riding, $2^{\text {nd }}$ ed. The Buildings of England Series (Harmondsworth: Penguin, 1995), 606; Thomas Allen, A New and Complete History of the County of York, 6 vols. (London, 1828-31), 4: 85-86). 
commemorative pall draped over the hearse during the funeral. ${ }^{2}$ The fabric is overlaid with the trunk and branches of a tree. Two roots emerge - seemingly from underneath the pall - and join together to form a trunk running down the center of the monument, which sprouts into thirteen branches terminating in miniature human heads (Figs. 2 and 3). At the couple's feet, the end of the trunk bursts into a spray of foliage. Shields hang from two additional branches; spindly in appearance and positioned near the bottom of the monument, these escutcheons seem to defy gravity by turning upwards towards the two effigies. A larger triangle of stone (possibly_another shield) is placed at the point where the roots growing between the couple's necks join together. Many of the usual markers of identity and status, such as dress, jewelry or armor, are omitted; only the lost heraldry on the shields, along with the expense and location of the monument itself, would have signaled the deceased couple's rank. The overall impression is strange and arresting, a juxtaposition of life and death, fusing the recumbent bodies of the spouses with the organic forms of stems, leaves and branches.

The hairstyles of the effigies date the Lowthorpe tomb to the second quarter of the fourteenth century, yet the only other surviving example of a tree growing from the effigy of the deceased was made over two hundred years later at the end of the sixteenth century. ${ }^{3}$ The uniqueness of its design may explain why the monument at

${ }^{2}$ Christopher Daniell, Death and Burial in Medieval England, 1066-1550 (London: Routledge, 1997), 47; Roberta Gilchrist, Medieval Life: Archaeology and the Life Course (Woodbridge: Boydell Press, 2012), 192.

${ }^{3}$ See the brass to Francis Palmes at Otley, Yorks (1593), illustrated in Jerome Bertram, Monumental Brasses as Art and History (Stroud: Alan Sutton, 1996), fig. 43. For the dating of the Lowthorpe tomb, see below. 
Lowthorpe has been largely ignored in the literature on English late-medieval art, which has tended to emphasize authority and tradition over novelty and innovation. ${ }^{4}$ This narrative is particularly prominent in studies on funerary monuments. In an important article on the patronage and design of memorials Nigel Saul commented that, "a notable characteristic of English late medieval tomb design was its conservatism, its attachment to traditional models." 5 Saul argued that the commemorative function of funerary sculpture encouraged artistic conservatism, since aristocratic patrons sought traditional designs in order to proclaim the ancestry of their lineage and continuity of their noble status. ${ }^{6}$ This is a persuasive explanation for the generally formulaic nature of late-medieval tombs, but does not account for the few monuments with radically different designs, such as the ciborium tomb of Aveline de Forz at Westminster Abbey (ca. 1295), the transi tomb of Archbishop Chichele at Canterbury Cathedral (complete by 1426), or the arboreal monument at Lowthorpe. ${ }^{7}$ Paul Binski's recent work has sought to reclaim the origins of artistic

\footnotetext{
${ }^{4}$ For the main literature on the Lowthorpe tomb, see note 11 below.
}

${ }^{5}$ Nigel Saul, "Patronage and Design in the Construction of English Medieval Tomb Monuments," in Patrons and Professionals in the Middle Ages, ed. Paul Binski and Elizabeth A. New (Donington: Shaun Tyas, 2012), 316-32, at 329.

${ }^{6}$ Ibid, 331.

${ }^{7}$ For the monument to Aveline de Forz, see Paul Binski, Westminster Abbey and the

Plantagenets: Kingship and the Representation of Power (New Haven: Yale

University Press, 1995), 113-15. For the transi tomb of Archbishop Chichele, see

Christopher Wilson, "The Medieval Monuments," in A History of Canterbury

Cathedral, ed. Patrick Collinson, Nigel Ramsay and Margaret Sparks (Oxford:

Oxford University Press, 1995), 451-510, at 476-81. 
innovation from the Renaissance, analyzing the philosophical and theological underpinnings for the idea of invention in the medieval period. ${ }^{8} \mathrm{He}$ argues that postmodern and anthropological approaches have demoted (explicitly or implicitly) the idea of invention in the Middle Ages, the former due to a denial of authorial agency, the latter because of their emphasis on the instrumentality of artworks. ${ }^{9}$ This article is a response to Binski's call for art historians to treat the idea of what invention consisted of in the Middle Ages as "an intellectually serious issue." the novelty and inventiveness of the Lowthorpe tomb, considering what this unique monument might reveal about the processes of artistic innovation in late-medieval England.

\section{THE LOWTHORPE TREE}

THE most novel aspect of the tomb at Lowthorpe is the tree that seems to emerge from under the funerary pall covering the effigies (Fig. 1). It has thirteen branches: six on the right-hand side (over the body of the woman) and seven on the left (over the body of the man) (Fig. 4). All are placed at regular intervals, except the first branch on the left-hand side, which has been squeezed into the space directly below the head of the male effigy. Whereas the others sprout from the main trunk of the tree, this branch is attached to the root growing over the man's body. This irregular arrangement suggests that the number of branches was deliberate and meaningful, the

${ }^{8}$ Paul Binski, Gothic Wonder: Art, Artifice and the Decorated Style, 1290-1350 (New Haven and London: Yale University Press, 2014), 49-79; idem, "Notes on Artistic Invention in Gothic Europe," Intellectual History Review 24, no. 3 (2014), 287-300.

\footnotetext{
${ }^{9}$ Binski, “Artistic Invention,” 295-97.

${ }^{10}$ Ibid, 297.
} 
designer compromising visual symmetry in order to fit an uneven number into the available space. The ends of the branches sprout miniature human heads, turning inwards so that the two rows face one another. These were first recognized in three pioneering articles by Sophie Oosterwijk, who overturned Kurt Bauch's interpretation of the tomb as a form of cadaver monument with the heads mistakenly identified as toads. ${ }^{11}$ Although the faces are badly worn, it is still possible to discern their main features (indicated on my diagram of the monument), the only exception being the head at L2 which has a large diagonal section broken off (Fig. 4). ${ }^{12}$ All the heads are individualized (Fig. 5). Some have their hair in two large curls, whereas others have it cropped close to the head. One man is depicted with a full beard, thick curly hair and prominent ears [R5]. There are two female heads, one of which wears a long veil [L3], while the other has her hair gathered at her temples and wears a shorter veil with a wimple [R3].

${ }^{11}$ Kurt Bauch, Das mittelalterliche Grabbild (Berlin: de Gruyter, 1976), 253, fig. 376; Sophie Oosterwijk, "Deceptive Appearances: the Presentation of Children on Medieval Tombs," Ecclesiology Today, 42 (2010): 45-60, at 47-49; eadem, “"Food for Worms- Food for Thought': the Appearance and Interpretation of the 'Verminous Cadaver in Britain and Europe," Church Monuments, 20 (2005): 40-80, at 61-62; eadem, “'A Swithe Feire Graue': The Appearance of Children on Medieval Tomb Monuments," in Family and Dynasty in Late Medieval England, Harlaxton Medieval Studies 9, ed. Richard Eales and Shaun Tyas (Donington: Shaun Tyas, 2003), 172-92, at 179 .

12 The letter and number in square brackets denote the position of the miniature heads, as indicated in my diagram of the monument (Fig. 4.). 
Close examination reveals another detail previously unnoticed by commentators on the monument. Six of the heads are tonsured (Figs. 4 and 6). The uneven erosion of the limestone means that some of these tonsures are clearly delineated [R2, R4, L6], whereas others are much more difficult to discern [R6, L4, L5]. In all cases, however, these heads are differentiated from those representing laymen by the outline of the corona cut into the stone, the smooth bald scalp contrasting with the incised wavy lines of the surrounding hair (Figs. 3 and 6). ${ }^{13}$ This distinction between skin and hair would have been more noticeable in the fourteenth century, when (as was usual for limestone monuments) the tomb would have been fully painted. ${ }^{14}$ There is no obvious pattern in the distribution of clerics and laity: the

${ }^{13}$ The tonsure refers to the razing in general, whereas the corona denotes the circle on the top of the head. See Louis Trichet, La tonsure: vie et mort d'une pratique ecclésiastique (Paris: Éditions du Cerf, 1990), 109.

${ }^{14}$ Nigel Saul, English Church Monuments in the Middle Ages: History and Representation (Oxford: Oxford University Press, 2011), 90. For example, the latefourteenth-century limestone effigies of Sir Roger de Boys and Lady Margaret at Ingham (Norfolk), their extensive polychromy detailed in Helen Howard, "Scientific Examination of the Polychromy of the de Ingham and de Bois Tombs at Ingham, Norfolk," (conservation report, wall paintings department, Courtauld Institute of Art, 1993). For a wider discussion of polychromy and sculpture, see Roberta Panzanelli (ed.), The Color of Life: Polychromy in Sculpture from Antiquity to the Present (Los Angeles: Getty Publications, 2008); David Park, “The Polychromy of English Medieval Sculpture," in Wonder: Painted Sculpture from Medieval England, ed. Stacey Boldrick, David Park and Paul Williamson (Leeds: Henry Moore Institute, 2002), 30-54. 
left-hand side has three tonsured heads bunched together [L4, L5, L6], while the right alternates between tonsured and non-tonsured heads [R2, R4, R6]. In some cases the corona is restricted to the crown of the head $[\mathrm{R} 2, \mathrm{R} 4, \mathrm{~L} 4, \mathrm{~L} 6]$, whereas in others it covers almost the entire scalp, with only a narrow ring of hair remaining [R5, L5]. Ecclesiastical councils in the later Middle Ages sometimes prescribed larger tonsures for monks and smaller for secular clerics, but this distinction is not typically followed in images of ecclesiastics from the same period. ${ }^{15}$ The gap between ecclesiastical regulations and artistic representation can also be seen in the length of the hair: aside from R6 and L5, all of the tonsured heads have long hair covering their ears. Although ecclesiastics were traditionally required to have their hair shorn above the ears, images of secular clerics (and even monks) from the fourteenth century frequently combine flowing locks with a corona. ${ }^{16}$ While it is difficult to determine the meaning - or lack thereof - in the variations between the tonsured heads, it is certain that medieval viewers would have recognized them as ecclesiastics.

\section{‘COLLATIO’: INVENTION FROM MODELS}

IN order to understand the novelty of the tree at Lowthorpe, we must first consider its possible artistic and literary models. Whereas copying and invention are now thought of as opposing concepts, in the Middle Ages the thoughtful gathering of models (often

15 Trichet, La tonsure, 118-19 (see also the images at 123, 127, 137).

${ }^{16}$ For examples of tonsured clerics with hair covering their ears, see Malcolm Norris, Monumental Brasses: The Portfolio Plates of the Monumental Brass Society, 18941984 (Woodbridge: Boydell Press, 1988), figs. 13, 25, 27, 29, 35, 39, 41, 45, 46, 56, 59, 60, 61, 62; Trichet, La tonsure, 123, 127. 
termed collatio) was seen as a necessary prelude to invention. ${ }^{17}$ In his Exhortationes, a collection of sermon outlines, the influential English preacher John Bromyard (d. 1352) describes the creative process of painters:

...who diligently ponder beautiful images in order to make similar ones: they gather together [colligunt] one excellent beauty and treatment from one picture, and one from another, in such a way that they place all these excellent features in one most beautiful picture. ${ }^{18}$

In this account the artist neither copies artistic traditions slavishly nor rejects them wholesale, instead producing a "most beautiful picture" through the gathering and mixing of existing ideas into a new combination. It is possible that this description was based upon Bromyard's actual experience of artists at work. At the very least, since illustrations in sermons need to be credible to be effective, it must represent his idea of a process that would have been plausible to his audience. ${ }^{19}$ While Bromyard was unusual in applying these principles to artistic invention, his description of collatio repeats a common trope in rhetorical treatises (such as Cicero's De

\footnotetext{
${ }^{17}$ Binski, Gothic Wonder, 65-67.
}

18 “...conditiones consequamur pictorum qui pulcras imagines diligentur considerant ut consimiles faciant. Et unam excellentem pulcritudinem vel tractum colligunt de una imagine et aliam de alia ut omnes illas excellentias in una imagine ponant et pulcerrimam faciant.” John Bromyard, Exhortationes 7.7 (Cambridge, University Library MS Kk iv 24, fols. 1r-120v). This excerpt is published in Keith Walls, John Bromyard on Church and State (Market Weighton: Clayton-Thorpe Publishers, 2007), 27n134. The translation is from Binski, Gothic Wonder, 66.

${ }^{19}$ Binski, Gothic Wonder, 66; idem, “Artistic Invention,” 287. 
inventione), which refer to the "inventory" of models as the material that the author re-shapes and re-assembles to create new literary compositions. ${ }^{20}$

Although the Lowthorpe tomb has been described as a "family tree," ${ }^{21}$ there was no straightforward visual model for this concept in fourteenth-century England. ${ }^{22}$

${ }^{20}$ Binski Gothic Wonder, 66; idem, “Artistic Invention,” 287. See also Mary Carruthers, The Book of Memory, $2^{\text {nd }}$ ed. (Cambridge: Cambridge University Press, 2008), 243-49, 258, 309; eadem, The Craft of Thought (Cambridge: Cambridge University Press, 1998), 11-12, 64, 154.

${ }^{21}$ Oosterwijk, "Deceptive Appearances," 47; eadem, "Food for Worms," 61; eadem, "Swithe Feire Graue," 179.

${ }^{22}$ Although this article focuses primarily on visual models (with a short discussion of scholastic and medical texts below), it is important to note that the tree was a common literary metaphor in the Middle Ages, with arboreal imagery abounding in texts ranging from devotional and mystical writings, romances, sermons, and scholastic tracts, to name but a few. See Mary Franklin Brown, Reading the World: Encyclopedic Writing in the Scholastic Age (Chicago and London: University of Chicago Press, 2012), especially the chapter on Ramon Llull's Arbor scientiae at 129181; Maryanne Cline Horowitz, Seeds of Virtue and Knowledge (Princeton, N. J.: Princeton University Press, 1998), especially 57-80; John Whitman, “The Body and the Struggle for the Soul of Romance: La Queste del Saint Graal," in The Body and the Soul in Medieval Literature, ed. Piero Boitani and Anna Torti (Cambridge: D. S. Brewer: 1999), 31-62, at 43-60. A useful overview of the various facets of tree symbolism (from an art-historical perspective) is found in the recent collection of essays edited by Pippa Salonius and Andrea Worm, The Tree: Symbol, Allegory, and 
Diagrams that use the form of a tree to illustrate the successive generations of a particular family did not become popular until the late fifteenth century: one notable example is a diagram from the sixteenth-century Codex Maggi, which shows the trunk and branches of a tree overlaid with small roundels inscribed with the names of successive generations of the Magius family. ${ }^{23}$ While earlier genealogical charts were referred to as "arbores," their diagrammatic design bears little resemblance to a naturalistic tree: an arbor consanguinitatis (a legal diagram showing the limits within which consanguinity was a bar to marriage), added to a manuscript of canon law by an English artist in ca. 1300-20, consists of roundels clustered into an arrow shape and superimposed onto the body of a crowned male figure, its arboreal imagery confined to the two leafy branches held in the king's hands. ${ }^{24}$ In her study of the genesis of the family tree Christiane Klapisch-Zuber emphasized the long resistance in the Middle Ages to representing lay genealogies in the form of a tree, a reluctance

Mnemonic Device in Medieval Art and Thought, International Medieval Research 20

(Turnhout: Brepols, 2014).

${ }^{23}$ Paris, Bibliothèque Nationale de France, Réserve du Cabinet des Estampes, Ad

134. For the development of the image of the 'family tree', see Christiane KlapischZuber, "The Genesis of the Family Tree," I Tatti Studies in the Italian Renaissance, 4 (1991): 105-29; Klapisch-Zuber, L'ombre des ancêtres: essai sur l'imaginaire médiéval de la parenté (Paris: Fayard, 2000); and Marigold Anne Norbye, “Arbor Genealogiae: Manifestations of the Tree in French Royal Genealogies," in Salonius and Worm, The Tree, 69-93.

${ }^{24}$ London, British Library [hereafter BL] MS Royal 10 D VII, fol. 257v. For illustrations see Scott McKendrick, John Lowden and Kathleen Doyle, eds., Royal Manuscripts: the Genius of Illumination (London: British Library, 2011), 320-23. 
which she attributed to the contradiction between the descending order of medieval genealogies and the ascending structure of the tree. ${ }^{25}$ She argued that the "upwards thrust" of the tree was much better suited to expressing spiritual relationships, as seen on a fourteenth-century seal from Trinity Hall, Cambridge that depicts the disembodied heads of the collegiate canons sprouting from two branches framing the arms of the founder and an image of the Trinity (Fig. 7). ${ }^{26}$

Perhaps the closest conflation of genealogical and arboreal imagery in the fourteenth century was the Tree of Jesse, an image of the ancestry of Christ drawing on the arboreal metaphors in Isaiah's prophecy ("and there shall come forth a rod out of the stem of Jesse, and a branch shall grow out of his root"), as well as the genealogical lists in the Gospels of Matthew and Luke. ${ }^{27}$ Although the iconography of the Tree of Jesse varied across different periods and places, it typically comprised a tree growing from the recumbent body of Jesse, its trunk framing images of the Virgin and Christ, while the outer branches housed prophets and Old Testament kings. ${ }^{28}$ The Tree of Jesse was not intended as an exhaustive genealogical record; rather, it represented a conflation of spiritual and consanguineous lineage in which those who

${ }^{25}$ Klapisch-Zuber, "Family Tree," 111-24.

${ }^{26}$ Klapisch-Zuber, "Family Tree,” 125-27. For the Trinity Hall seal, see Mark Ryan Geldof, "Signo Dicti Collegii: Instruction for a Fourteenth-Century Corporate Badge for the College of Trinity Hall, Cambridge," The Antiquaries Journal, 91 (2011): 16373 , at $168-69$.

27 "et egredietur virga de radice Iesse et flos de radice eius ascendet" (Isaiah 11.1). For Christ's genealogy, see Matthew 1. 1-17 and Luke 3. 23-38.

${ }^{28}$ Claus M. Kauffmann, Biblical Imagery in Medieval England, 700-1550 (London: Harvey Miller, 2003), 130-33. 
prophesied Christ's birth, as well as His most illustrious ancestors, were accorded a place in the 'family tree.' The spiritual facet of the Jesse Tree is emphasized by its placement in illuminated Psalters: it commonly decorated the Beatus initial at the beginning of Psalm 1, juxtaposed with verses that compared the virtuous man to "a tree planted by streams of water." 29

The Tree of Jesse and the Lowthorpe monument share a distinctive feature: both display an intimate connection between the recumbent figure(s) and the tree. In the case of the Tree of Jesse, the trunk typically sprouts from the chest of the sleeping patriarch (although the root itself is often hidden by drapery); at Lowthorpe the trunk splits and turns towards the two effigies before curving inwards to disappear underneath the funerary pall, suggesting that the ultimate, hidden source of the tree is the bodies of the two effigies (Fig. 2). A connection between the Lowthorpe tree and the Tree of Jesse has previously been proposed by Sally Badham, Sophie Oosterwijk and Nigel Saul. ${ }^{30}$ Both artist and patron of the Lowthorpe tomb would have been familiar with this image. The Jesse Tree was particularly popular in fourteenthcentury England, depicted in wall paintings, manuscript illuminations and stained

29 "lignum quod plantatum est secus decursus aquarum." This verse is transcribed from the St Omer Psalter (BL, MS Yates Thompson 14, fol. 7), and is derived from Psalm 1:3. See also Arthur N. Watson, The Early Iconography of the Tree of Jesse (London: Oxford University Press, 1934), 144-45.

${ }^{30}$ Sally Badham and Geoff Blacker, Northern Rock: The Use of Egglestone Marble for Monuments in Medieval England, British Archaeological Reports [BAR] British Series 480 (Oxford: Archaeopress, 2009), 22; Oosterwijk, "Food for Worms," 62; Saul, English Church Monuments, 136. 
glass, including the east window of nearby Selby Abbey (Yorkshire, N. R.). ${ }^{31}$ The visual parallel with the Lowthorpe monument is strengthened by the fact that a number of Jesse Trees from the late-thirteenth and fourteenth centuries are depicted with disembodied heads. ${ }^{32} \mathrm{~A}$ wall-painting in the nave of Black Bourton church (Oxfordshire), executed between ca. 1250 and ca. 1275, shows the branches of the tree framing full-length figures of the Virgin and Child and Christ in Majesty, flanked by two male heads, possibly representing SS Peter and Paul (Fig. 8). ${ }^{33}$ In other cases, the design of the tree bears an even closer resemblance to the Lowthorpe memorial: a full-page illumination from the Rothschild Canticles, made in Bergues-Saint-Winnoc

${ }^{31}$ For the popularity of Jesse Trees, see Peter Coss, "Knighthood, Heraldry and Social Exclusion in Edwardian England," in Heraldry, Pageantry and Social Display in Medieval England, ed. Peter Coss and Maurice Keen (Woodbridge: Boydell Press, 2002), 39-68, at 53-54. The original Jesse window at Selby was executed ca. 1339ca. 1344, but was replaced with a copy in 1906 following a fire (David O'Connor and Henrietta Harris, “The East Window of Selby Abbey, Yorkshire," in Yorkshire Monasticism: Archaeology, Art and Architecture from the $7^{\text {th }}$ to $16^{\text {th }}$ Centuries, British Archaeological Association Conference Transactions 16, ed. Lawrence Hoey (Leeds: Maney, 1995), 117-45).

${ }^{32}$ For examples in illuminated manuscripts, see BL MS Lansdowne 346, fol. 7; BL MS Yates Thompson 19, fol. 18r; Oxford, Bodleian Library MS Liturg. 396, fol. 15v; Paris, Bibliothèque Nationale MS fr. 567, fol. 15r.

${ }^{33}$ E. W. Tristram with Monica Bardswell, English Medieval Wall Painting: The Thirteenth Century (Oxford: Oxford University Press, 1950), 1: 245-46. 
at the end of the thirteenth century, depicts the Jesse Tree as a single vertical trunk with curving lateral branches, each sprouting a disembodied crowned head (Fig. 9). ${ }^{34}$ Although an unusual iconography for funerary monuments, there are a handful of fourteenth-century memorials that incorporate the Tree of Jesse in their design. ${ }^{35}$ At the east end of the north aisle in the church of St. Bartholomew, Ducklington (Oxfordshire) a double tomb canopy was carved to resemble a tree with two long branches, one growing over each ogee-shaped arch, both sprouting eight disembodied human heads (Fig. 10). ${ }^{36}$ Although the canopies at Ducklington have been much

${ }^{34}$ Yale, Beinecke Library MS 404, fol. 48r. See Jeffrey Hamburger, The Rothschild Canticles: Art and Mysticism in Flanders and the Rhineland circa 1300, (New Haven: Yale University Press, 1990), 8, 89-91; Barbara Newman, "Contemplating the Trinity: Text, Image, and the Origins of the Rothschild Canticles," Gesta 52, no. 3 (2013): 133-60; Alison Stones, Gothic Manuscripts 1260-1320: Part One, 2 vols. (London: Harvey Miller, 2013), 2: 516-29. An abbreviated version of the same design decorates an initial at the beginning of the genealogy of Christ from the Gospel of Matthew in a manuscript made at Cambrai in 1266 (Cambrai, Médiathèque Municipale MS 189, fol. 163).

${ }^{35}$ For an earlier example, see the $12^{\text {th }}$-century Tournai marble tomb slab at Lincoln Cathedral with a Jesse Tree carved in low relief, discussed in T. A. Heslop, "Art, Nature and St Hugh's Choir at Lincoln," in England and the Continent in the Middle Ages: Studies in Memory of Andrew Martindale: Proceedings of the 1996 Harlaxton Symposium, ed. John Mitchell with assistance from Michael Moran (Stamford: Shaun Tyas, 2000), 73, fig. 6 .

${ }^{36}$ Jennifer Sherwood and Nikolaus Pevsner, Oxfordshire, The Buildings of England Series (Harmondsworth: Penguin, 1974), 588-89; Alan Crossley and C. J. Curry, eds., 
altered and possibly wholly reset, it is still possible to discern the figure of Jesse at the point where the two arches meet, lying asleep with his head resting on his hand and legs crossed (Fig. 11). ${ }^{37}$ The niches would originally have housed memorials, possibly effigies of a husband and wife, an arrangement found on a number of fourteenthcentury monuments in the Thames Valley. ${ }^{38}$ By framing the tombs within a Jesse Tree, the Ducklington monument created an association between the deceased and the family of Christ, a connection that expressed hope in their place amongst the saved. A similar idea is represented on a memorial to two bishops of Schwerin, the brothers Gottfried and Friedrich von Bülow, made in Tournai in around 1375, the largest

"Ducklington: Churches," in The Victoria History of the County of Oxford, vol. 13 (London: Institute of Historical Research, 1996), 143-44.

${ }^{37}$ Crossley and Curry, "Ducklington: Churches,"144.

${ }^{38}$ See especially the fourteenth-century double-niche tomb at nearby Witney with the recumbent effigies of a man and woman (Sherwood and Pevsner, Oxfordshire, 589; Crossley and Curry, "Ducklington: Churches," 143-44). Double-niche tombs are also found at Minchinhampton, Glos. (effigies of a man and woman), Northmoor, Oxon. (effigies of a man and woman in the western niche and cross slabs in the eastern niche), Sparsholt, Berks. (effigies of a man and woman), and Shottesbrooke, Berks. (niches now empty). See Sally Badham, "The de la More Effigies at Northmoor (Oxfordshire) and Related Monuments at Winterbourne (Gloucestershire), Church Monuments, 23 (2008): 14-44, at 15-19; Nigel Saul, "Shottesbrooke Church: A Study in Knightly Patronage," in Windsor: Medieval Art, Archaeology and Architecture in the Thames Valley, ed. Laurence Keen and Eileen Scarff, British Archaeological Association Conference Transactions 25 (Leeds: Maney, 2002), 262-81, at 272-73. 
surviving medieval brass in Europe (Fig. 12). ${ }^{39}$ The margins of the brass are occupied by the undulating trunk of a Jesse Tree. Jesse himself sleeps in the center of the lower border and Christ is seated at the top, while the rest of the tree is occupied by twentysix figures, all but one of whom are crowned and hold a musical instrument. The commemoration of the deceased is closely linked to this sacred iconography. The trunk of the Tree of Jesse is inscribed with epitaphs to Gottfried and Friedrich, the beginning and end of the text marked by the figure of Christ (a role appropriate for the Alpha and Omega). ${ }^{40}$ Like the Lowthorpe memorial, the Schwerin brass features shields hanging from the branches of the tree, in this case four helms with escutcheons displaying the heraldry of the von Bülow family.

While their later dates means that the monuments at Schwerin and Ducklington cannot have acted as direct models for the Lowthorpe tomb, considering the memorials together exposes an artistic culture in which sacred iconography was used to affirm and dignify dynastic lineage. This idea is also expressed in a group of fourteenth-century Jesse windows which incorporate images of kneeling donors. The east window at St. Mary's Shrewsbury (Shrops.) features a magnificent Tree of Jesse with kneeling images of Sir John de Charleton, his wife Hawise and four children in

${ }^{39}$ J. Bracken, “The Schwerin Brasses,” Monumental Brass Society Bulletin, 57

(1991), 512-17; H. K. Cameron, "The Fourteenth-Century School of Flemish

Brasses," Transactions of the Monumental Brass Society, 11, no. 3 (1972, for 1970),

50-81, at 60; W. Creeny, A Book of Facsimiles of Monumental Brasses on the

Continent of Europe (London, 1884), 10-11; Malcolm Norris, Monumental Brasses:

The Craft (London: Faber, 1978), 74, fig. 146.

40 "I am the Alpha and Omega, the First and the Last, the Beginning and the End" (Revelation 22.13). 
the lowest register alongside an inscription asking for prayer on their behalf, while the unusual Jesse window at Dorchester Abbey (Oxon.), combining sculpture and stained glass, has a kneeling male donor carved in front of the standing king on the lowest section of the mullion immediately to the left of the sleeping patriarch. ${ }^{41}$ However, such comparisons also highlight the distinctive way in which the Tree of Jesse is treated on the Lowthorpe tomb. At Ducklington and Schwerin the Tree of Jesse merely frames the deceased, whereas at Lowthorpe the couple appropriate the iconography for themselves, taking on the role of Jesse with their own sacred tree sprouting from their bodies (Fig. 1).

The Tree of Jesse is unlikely to have been the only model for the Lowthorpe tomb. One notable difference is that the tree at Lowthorpe grows out of two bodies rather than one. There does not appear to be another surviving example before the end of the fifteenth century of a tree depicted sprouting from the bodies of a man and

${ }^{41}$ For Dorchester Abbey, see Peter Newton, The County of Oxford: A Catalogue of Medieval Stained Glass, Corpus Vitrearum Medii Aevi of Great Britain 1 (London: Oxford University Press, 1979), 83-84; Warwick Rodwell, Dorchester Abbey, Oxfordshire: The Archaeology and Architecture of a Cathedral, Monastery and Parish Church (Oxford and Oakville: Oxbow Books, 2009), 84-90, fig. 84. For Shrewsbury see Coss, "Knighthood," 54-56. For other examples of fourteenth-century Jesse windows with donor figures, see the parish churches at Lowick (Northants.), Mancetter (Warws.) and Merevale (Warws.), discussed in Coss, "Knighthood," 4956; Peter Newton, "Schools of Glass Painting in the Midlands," (Ph. D thesis, Courtauld Institute of Art, 1962), 2: 336-51, 3: 570-81, 890-936. 
woman. ${ }^{42}$ The closest medieval parallel may be found in the writings of William of Auvergne, a theologian and bishop of Paris from 1228 until his death in 1249. ${ }^{43}$ Auvergne's discussion of marriage (part of his treatise on the sacraments, which in turn formed one of seven sections of his Magisterium divinale et sapientiale) employs the extended metaphor of Christian marriage as a verdant and fruitful tree, planted and cultivated by God. ${ }^{44}$ This tree grows from the convergence of male and female as if from two branches. ${ }^{45}$ William uses this arboreal imagery to illustrate the

${ }^{42}$ Depictions of the Holy Kinship on Flemish altarpieces from the end of the $15^{\text {th }}$ and beginning of the $16^{\text {th }}$ centuries occasionally show a tree growing from the bodies of either Anne and Joachim or Hysmeria and Ephraim, its branches sprouting with figures of their descendants in much the same way as the Tree of Jesse. For examples, see Ton Brandenburg, "St. Anne and Her Family. The Veneration of St. Anne in Connection with Concepts of Marriage and the Family in the Early Modern Period," in Saints and She-Devils: Images of Women in the Fifteenth and Sixteenth Centuries, ed. Lène Dresen-Coenders (London: Rubicon Press, 1987), 101-29.

${ }^{43}$ Roland Teske, Studies in the Philosophy of William of Auvergne (Milwaukee, Wis.: Marquette University Press, 2006), 17-18. See also Franco Morenzoni and Jean-Yves Tilliette, eds., Autour de Guillaume d'Auvergne (†1249) (Turnhout: Brepols, 2005). ${ }^{44}$ William of Auvergne, "De sacramento matrimonii," in Guilielmi Alverni... Opera Omnia, ed. Joannem Dupuis, vol. 1 (Paris, 1674), 512-13. For an analysis of the arboreal metaphors in Auvergne's theology of marriage, see Philip L. Reynolds, How Marriage Became One of the Sacraments (Cambridge: Cambridge University Press, 2016), 506-11.

${ }^{45}$ Auvergne "De sacramento matrimonii," 513 (column 1, section A). 
interdependence of men and women, whose basic natures are incomplete and impotent unless joined together:

For human nature, like a most noble tree, or a most precious planting of God the horticulturist, [consists] as it were of two branches, and is [made of] male and female; the proof hereof is the power to bring forth children, which dwells in both branches alike, but is not complete in either of them [on its own], having part of itself in one and part in the other. ${ }^{46}$

It is in this state of perfect union that a marriage is able to generate the "fructus" of children; conversely, William argues that a fruitful marriage with many offspring is a sign of God's blessing on the couple. ${ }^{47}$ Although Auvergne's particular metaphor of marriage as the joining of two branches is not found in other scholastic treatises, the use of arboreal imagery to discuss the family is a common trope in medieval texts: one striking example is found in the thirteenth-century Arthurian romance Queste del Saint Graal, in which the Grail knight Bors is counseled by a priest that his parents "formed one tree and one flesh, and since you are the fruit of that tree you should be as good as it was." $" 48$

46 "Siquidem natura humana, velut arbor nobilissima, et Dei agricolantis plantatio preciosissima, velut ex duobus ramis est masculus, scilicet, et foemina, cuius indicium est vis generativa, quae ambobus istis ramis insimul indita est, in neutro vero eorum completa, sed partem sui habens in altero et partem in altero.” Auvergne, "De sacramento matrimonii”, 513 (column 1, section A).

${ }^{47}$ Ibid., 513 (column 2, sections B-D).

48 “cil doi furent vn seul arbre. \& vne meisme charz par coniunction de mariage. \& puis que voz en estes fruis. voz deues estre bons. car li arbre furent bon." Elizabeth 
This symbolism found visual expression in illuminations accompanying Trees of Affinity (arbores affinitatis): charts that illustrated the degrees of kinship contracted through marriage, commonly used to establish inheritance rights and matrimonial alliances. ${ }^{49}$ These legal diagrams appear in canon law texts from the midtwelfth century onwards, often accompanied by the image of a couple flanking a flowering tree.$^{50}$ A copy of the Decretum Gratiani from the mid-thirteenth century (now held at the Médiathèque Municipale in Cambrai) has a Tree of Affinity set against rich arboreal imagery (Fig. 13). ${ }^{51}$ Directly above the diagram, a couple stands side-by-side facing one another with their hands joined across the trunk of the tree that grows between them. The couple is shown again at the bottom of the page, this time seated on a bench; each figure holds the trunk of a tree with one arm and uses the other to embrace their spouse. This image of unity in two bodies is reflected in the tree behind the couple's heads, its leafy crown composed of two distinct boughs. A late-thirteenth century table of affinity, made in Paris, also uses the tree motif to illustrate the joining together of husband and wife: the tree is composed of two branches, each grasped by one of the spouses, which join together to form a single

M. Willingham, ed., La queste del Saint Graal, from the Old French Lancelot of Yale 229, with Essays, Glossaries, and Notes to the Text (Turnhout: Brepols, 2012), 137.

${ }^{49}$ McKendrick, Lowden and Doyle, Royal Manuscripts, 320; Watson, Tree of Jesse, 39.

${ }^{50}$ McKendrick, Lowden and Doyle, Royal Manuscripts, 320. See also Hermann Schadt, Die Darstellungen der Arbores consanguinitatis und der Arbores affinitatis: Bildschemata in juristischen Handschriften (Tübingen: Wasmuth, 1982).

${ }^{51}$ Cambrai, Médiathèque Municipale MS 605 (563), fol. 292v. See Schadt, Arbores, 224, fig. 94. 
trunk. ${ }^{52}$ Ribbons of text burst from the point where the two branches meet, creating arches which link to the diagram below. The same idea is expressed in an earlyfourteenth century diagram made in England, which depicts a woman touching a red branch and a man a blue branch, their vine-like tendrils interweaving to produce the appearance of a single tree (Fig. 14). ${ }^{53}$

I have presented a possible inventory of the types of artistic and literary models from which the tree at Lowthorpe could have taken its form. Any attempt to 'rewind' the process of invention necessarily involves a degree of informed conjecture, yet this exercise also enables us to define the inventive qualities of the Lowthorpe tomb more precisely. The novelty of the design at Lowthorpe may have resulted from the synthesis of at least two different iconographic types, the Tree of Jesse and the Tree of Affinity. If the designer of the Lowthorpe tomb did draw on these models, then s/he was also adapting them in ways that suggest a sophisticated understanding of their theological significance: the tree with two branches familiar

${ }^{52}$ Paris, Bibliothèque Sainte-Geneviève MS 1212. See Stones, Gothic Manuscripts:

Part 1, vol. 2, 36-37. For illustrations, see the Bibliothèque virtuelle des manuscrits médévieux, s.v. "Paris, Bibliothèque Sainte-Geneviève 1212," accessed 25 November 2015, http://bvmm.irht.cnrs.fr/.

${ }^{53}$ Cambridge, Fitzwilliam Museum MS 262, fol. 71v. The provenance of the illuminations in this manuscript has been much debated. The most recent study attributes the illuminations to an English artist (and the text to a French scribe), arguing that the treatment of figures and foliage is closely comparable to the Tickhall Psalter group of manuscripts. See Susan L'Engle and Robert Gibbs, Illuminating the Law: Legal Manuscripts in the Cambridge Collections (London: Harvey Miller, 2001), 146-52. 
from affinity diagrams lies over the spouses themselves, its roots springing from their bodies in much the same way as the Biblical figure of Jesse. The monument is thus more complex and multivalent than a 'family tree.' If the joining of two branches was a metaphor for marriage, and a verdant tree a symbol for a blessed union, then this suggests an intellectual context in which the Lowthorpe monument could be seen as the display of a successful Christian marriage in addition to an image of family. As the memorials at Ducklington and Schwerin demonstrate, the tomb at Lowthorpe was far from unique in using sacred iconography to affirm dynastic lineage; rather, its novelty lies in the way in which these models have been fused onto the effigies themselves, intimately connected to the bodies of the deceased.

\section{AGENTS OF INVENTION}

AN account of models and influences must consider the agents who chose, adapted, transformed and executed these ideas. In Patterns of Intention, Michael Baxandall famously condemned art historians for using the concept of 'influence' in ways that obscured the active role of the artist in the process of creation. ${ }^{54}$ Yet identifying the agents responsible for innovation in medieval artworks is complicated by a lack of documentation, the collaborative methods of workshops, and the problem of defining

${ }^{54}$ Michael Baxandall, Patterns of Intention: On the Historical Explanation of Pictures (New Haven and London: Yale University Press, 1985), 58-60. See also Alixe Bovey, "Introduction: Influence and Illumination," in Under the Influence: The Concept of Influence and the Study of Illuminated Manuscripts, ed. Alixe Bovey and John Lowden (Turnhout: Brepols, 2007), vii-xiii, at viii. 
the respective roles of artist and patron. ${ }^{55}$ Traditionally, art historians have attempted to apply what is known about a few well-documented patrons and artists to other contexts for which this information is lacking. ${ }^{56}$ This is also true of tomb studies, where a handful of contracts and wills have been used to postulate broader trends in the relationship between patron and artist. These documents record workshops in fifteenth-century England (most notably that run by the alabaster sculptors Thomas Prentys and Robert Sutton) that were producing monuments to fairly standard designs, adjusted to suit the patron's budget and requirements. ${ }^{57}$ There are also references to patterns or designs (known, confusingly, as "patrons"), drawn up by the

${ }^{55}$ Kirk Ambrose, “Influence," Studies in Iconography Special Issue: Medieval Art History Today-Critical Terms, ed. Nina Rowe, 33 (2012), 197-206, at 200; Bovey, "Influence and Illumination," viii; Colum Hourihane, "Introduction", in Patronage, Power and Agency in Medieval Art, ed. Colum Hourihane (University Park, PA: Pennsylvania State University Press, 2013), xix- xxiv, at xix.

${ }^{56}$ Hourihane, "Introduction," xix.

${ }^{57}$ Saul, "Patronage and Design," 319. See also Sally Badham and Sophie Oosterwijk, ““Cest Endenture Fait Parentre': English Tomb Contracts of the Long Fourteenth Century", in Monumental Industry: The Production of Tomb Monuments in England and Wales in the Long Fourteenth Century, ed. Sally Badham and Sophie Oosterwijk (Donington: Shaun Tyas, 2010), 187-236; T. A. Heslop, “The Alabaster Tomb at Ashwellthorpe, Norfolk: its Workmanship, Cost and Location", in Patrons and Professionals in the Middle Ages, ed. Paul Binski and Elizabeth A. New (Donington: Shaun Tyas, 2012), 333-46. 
artist in negotiation with the patron. ${ }^{58}$ It has been argued that this process of largescale production discouraged innovation in English tomb design, the conservatism of patrons' tastes and the sculptors' attachment to traditional models mutually reinforcing. ${ }^{59}$

Like the overwhelming majority of monuments from the Middle Ages, the tomb at Lowthorpe has no surviving documentary evidence relating to its commissioning or manufacture. The bodies (and thus costumes) of the effigies are concealed by the funerary pall, meaning that dating the monument relies primarily on the hairstyles of the effigies and miniature heads, as well as comparisons with other semi-effigial monuments. The female effigy wears a shoulder-length folded veil draped over two coils of hair at her temples with loose strands framing her face, a style replicated on the miniature female head at L3 (Figs. 1, 2 and 5) ${ }^{60}$ This hairstyle appears on a number of funerary effigies and images of women in illuminated manuscripts from the early-fourteenth century. ${ }^{61}$ A particularly close parallel is found

${ }^{58}$ Badham and Oosterwijk, "Tomb Contracts," 200-05, 224-25, 229-31; Philip Lindley, Gothic to Renaissance: Essays on Sculpture in England (Stamford: Paul Watkins, 1995), 51-53, 63; Saul, "Patronage and Design,” 318-21.

${ }^{59}$ Saul, "Patronage and Design," 318-20, 331-32

${ }^{60}$ On the Howden effigy the loose hair is shown as two short curls just above eye level; at Lowthorpe the woman has longer strands flowing down her neck (Badham, Gittos and Gittos "Saltmarshe Chapel," 117-18).

${ }^{61}$ For other examples of the hairstyle (sometimes combined with a wimple), see the anonymous early-fourteenth century female effigy at Bedale (Yorks., N.R.) and Stevenage (Herts.), as well as the brass to Margaret de Camoys at Trotton (Sussex), usually dated to ca. 1310 (illustrated in Arthur Gardner, English Medieval Sculpture: 
on a female effigy at Howden Minster (Yorks., E.R.), recently re-dated to ca. 1325ca. 1330: the only difference being that on the Howden effigy the loose hair is shown as two short curls just above eye level, whereas at Lowthorpe the woman has longer strands flowing down her neck. ${ }^{62}$ The miniature female head at R3 has more The Original Handbook Revised and Enlarged with 683 Photographs (Cambridge: Cambridge University Press, 1951), figs. 398 and 408; Norris, Portfolio Plates, fig. 10). For examples in illuminated manuscripts, see Paris, Bibliothèque SainteGeneviève MS 329, fol. 246 (Paris, ca. 1315), and Amiens, Bibliothèque Municipale MS 360, fol. 266v (Paris, ca. 1300- ca. 1325).

62 The Howden tomb belongs to a group of richly carved knightly effigies in northern England, dubbed "Yorkshire Series B." The dating of these memorials has recently been reconsidered: while Brian and Moira Gittos used the dates of death of those commemorated to place this group of tombs between ca. 1300 and ca. 1317, David Park convincingly argued that they were in fact posthumous commissions, as the armor of the effigies and architectural details of their canopies are characteristic of the period ca. 1325 - ca. 1330 . The early dating is also challenged by Mark Downing, who instead places these monuments (dubbed "Group 5") in the period ca. 1330-40.). See Sally Badham, Brian Gittos and Moira Gittos, “The Fourteenth-Century Monuments in the Saltmarshe Chapel at Howden, Yorkshire: Their History and Context," Yorkshire Archaeological Journal, 68 (1996): 113-55, at 115-19; Mark Downing, "Military Effigies in Eastern England: Evidence of a High-Status Workshop of c. 1295-1350," in Monumental Industry: The Production of Tomb Monuments in England and Wales in the Long Fourteenth Century, ed. Sally Badham and Sophie Oosterwijk, (Donington: Shaun Tyas, 2010), 66-96, at 72-78; David Park, "Medieval Burials and Monuments," in The Temple Church in London: History, 
prominent coils of hair and a shorter veil combined with a wimple (Fig. 5). This style is also typical of the early-fourteenth century, featuring, for example, on the brass effigy of Joan Cobham (dated ca. 1320- ca. 1325), an anonymous female effigy at Alnwick (dated ca. 1330), and an image of a noblewoman from the Taymouth Hours (dated ca. 1325- ca. 1335). ${ }^{63}$ The drawing of the veil away from the forehead to reveal the two plaits, as depicted on this miniature head, was identified by the dress historian Margaret Scott as a typical feature of aristocratic fashions ca. $1330 .{ }^{64}$ Although the hair of the male effigy at Lowthorpe is less distinctive, the two large curls of hair that protrude from the fabric just below his ears (also depicted on the miniature male heads at L1, L2, L6, L7, and R1) are reminiscent of the male effigies at Howden and Bedale (both dated ca. 1325- ca. 1330) and the Setvans brass at Chartham, Kent (dated ca. 1323), all of which feature two fat rolls of hair at the man's jaw (Figs. 1 and 5). ${ }^{65}$ A final piece of evidence assists in dating the Lowthorpe monument. The design

Architecture, Art, ed. Robin Griffith-Jones and David Park (Woodbridge: Boydell Press, 2010), 67-91, at 89-91

${ }^{63}$ Illustrated in Gardner, English Medieval Sculpture, 205, fig. 402; Margaret Scott, $A$ Visual History of Costume (London: Batsford, 1986), 22. For the Taymouth Hours (BL, MS Yates Thompson 13, fol. 88 ), see Margaret Scott, Medieval Dress and Fashion (London: British Library, 2007), 92, fig. 53.

${ }^{64}$ Scott, Visual History of Costume, 24.

${ }^{65}$ The Howden and Bedale effigies both belong to the 'Yorkshire Series B' group, the dating of which is discussed in note 60 above. Badham, Gittos and Gittos, "Saltmarshe Chapel," 116; Park, "Burials and Monuments," 89. For an illustration of the Setvans brass, see Muriel Clayton, ed., Catalogue of Rubbings of Brasses and Incised Slabs (London: Board of Education, 1929), pl. 1, fig. 4. 
of the tomb is related to semi-effigial monuments, which typically comprise a coffinshaped slab carved with the bust of a praying figure at the top and religious and/or heraldic devices on the lower section. ${ }^{66}$ Semi-effigial monuments are concentrated in Lincolnshire and the East Riding, with the majority of surviving examples dating from the late-thirteenth and early-fourteenth centuries. ${ }^{67} \mathrm{~A}$ variation on this type is found at Nafferton (Yorks., E. R.), only one and a half miles from Lowthorpe, where a very worn monument depicts the busts of a man and woman in prayer, their bodies covered by a fluted pall with raised cusped decoration. ${ }^{68}$ Another close parallel to the Lowthorpe tomb is a memorial at Careby (Lincs.), dated ca. 1325-ca. 1335, which depicts the busts of an armored knight and lady with their hands clasped in prayer; the spouses' bodies are covered by a funerary pall and the female effigy has a long veil pulled back to reveal two coils of hair. ${ }^{69}$ The hairstyles of the effigies and the connection to semi-effigial monuments thus suggest that the Lowthorpe monument would fit best in the second quarter of the fourteenth century.

${ }^{66}$ See, for example, the monument to a member of the Disney family at Kingerby (Lincs.), dated ca. 1340- ca. 1350, illustrated in Saul, English Church Monuments, 46, fig. 9.

${ }^{67}$ Badham and Blacker, Northern Rock, 21.

${ }^{68}$ Pevsner and Neave, York and the East Riding, 619.

${ }^{69}$ For illustrations see Richard Deacon and Phillip Lindley, eds., Image and Idol: Medieval Sculpture (London: Tate Publishing, 2001), 45 (nn. 43-44), 62-63. A male and female effigy are also depicted lying beneath a funeral pall on a tomb at Stoke Rochford (also known as South Stoke), which was almost certainly made by the same workshop as the Careby monument. 
The size and ambition of the tomb at Lowthorpe indicates that the patron/s were from a prominent family. The most recent scholarship, based on research by Brian and Moira Gittos, has identified the effigies as representing Sir John de Heslerton and his wife Margery de Lowthorpe. ${ }^{70}$ Although there are no surviving documents or heraldry to confirm this association, the connection is persuasive. Sir John is listed as lord of the manor of Lowthorpe in the Nominum Villarum, a royal survey carried out in 1316, and enjoyed the right of presentment for clerical appointments (advowson) to the church of St. Martin from 1331 until his death in $1350 .{ }^{71}$ This means that the period of his lordship coincides with the probable dating of the monument to the second quarter of the fourteenth century. Sir John was clearly concerned with commemoration: in 1333 he founded a college of six perpetual

${ }^{70}$ Although the effigies have also been identified as Sir Thomas de Heslerton (d. after 1365) and his wife Alice Madingley, the majority of scholars in the last three decades have followed the more convincing attribution to Sir John and Margery suggested in Brian Gittos and Moira Gittos, “A Survey of East Riding Sepulchral Monuments before 1500," in Medieval Art and Architecture in the East Riding of Yorkshire, ed. Christopher Wilson, British Archaeological Association Conference Transactions 9 (London: British Archaeological Association, 1989), 99, 107 n. 32. See especially Oosterwijk, “"Food for Worms,” 40, 72 (n. 2).

71 "Nomina Villarum for Yorkshire," in The Survey of the County of York, ed. R. H. Skaife, Publications of the Surtees Society 49 (Durham, Andrews \& Co, 1867), 299368, at 312; “Notes of James Torre, 1690-94,” York, Minster Library, Torre MS LI/9, fol. 231. See also Carus V. Collier, "Lowthorpe and its Collegiate Church of St Martin," Transactions of the East Riding Antiquarian Society 24 (1921-22): 28-43, at 30-31. 
chantries at Lowthorpe, with the church of St. Martin rebuilt to house his new foundation. ${ }^{72}$ Although only the ruins of its contracted and much-altered chancel now survive, these remnants suggest an ambitious scheme: the chancel was built in the Decorated style with a crenellated cornice, large three-light windows with reticulated tracery, and finely-carved human heads on the exterior. ${ }^{73}$ While it was more common for memorials to be made close to the death of the commemorated, there are instances of patrons commissioning their own tombs decades before their death, often in conjunction with the foundation of chantries. A near-contemporary example is found in the case of John, third Baron Cobham (d. 1408), who founded Cobham college in 1362 and in ca. 1367 ordered brasses for himself and three family members to be laid in the chancel, but went on to live for another forty-one years after the commissioning of his memorial. ${ }^{74}$ As has been suggested by previous writers, it is likely that the tomb at Lowthorpe was connected to the rebuilding of the church of St. Martin, with Sir John taking advantage of the presence of masons and sculptors to commission a funerary monument for himself and his wife. ${ }^{75}$ Part of the explanation for the unusual design at Lowthorpe may lie in the active involvement of John and Margery as patrons of their own memorial.

${ }^{72}$ K. J. Allison, ed., "Parishes: Lowthorpe," in The Victoria History of the County of York: East Riding, vol. 2 (London: Institute of Historical Research, 1974), 276;

Pevsner and Neave, York and the East Riding, 606.

${ }^{73}$ Allison, "Parishes: Lowthorpe," 276-77; Pevsner and Neave, York and the East Riding, 606.

${ }^{74}$ Saul, English Church Monuments, 125-26

${ }^{75}$ Badham and Blacker, Northern Rock, 22; Gittos and Gittos, "East Riding Sepulchral Monuments," 107 n. 32. 
There is another potential agent in the creation of the Lowthorpe tomb. The foundation charters of Lowthorpe college name John de Hotham, Bishop of Ely (d. 1337) alongside the Heslerton family as a beneficiary of the chantries for the "founder and patron" of the college. ${ }^{76}$ A prominent supporter of Edward II, John de Hotham held a number of appointments in northern England, was elected bishop of Ely in 1316, and twice served as chancellor (1312-16 and 1327-28) ${ }^{77}$ His close association with John and Margery is evidenced in the marriage of his nephew to their eldest daughter Agnes (Fig. 15). ${ }^{78}$ Since there are no records of Bishop Hotham making a financial donation to Lowthorpe college, it is possible that his 'patronage' took a less tangible form, perhaps advising on the administration, organization and spiritual affairs of the new community. The Bishop thus provides a possible link between the monument and theological concepts of marriage as expressed by scholars like

${ }^{76}$ Calendar of the Patent Rolls Preserved in the Public Record Office: Edward III, vol. 2, 1330-1334 (London: H.M.S.O., 1893), 427; David Robinson, ed., The Register of William Melton, Archbishop of York, 1317-1340, vol. 6 (Woodbridge: Boydell Press, 2011), 197. The notes of antiquarian James Torre differ from the calendar of patent rolls and register of William Melton: the "chantry of the founder" is linked to the Heslerton family and John de Hotham, while the "chantry of the patron" is said to be for an unnamed "uncle of Sir John de Heslerton" ("Notes of James Torre, 169094”, fol. 231v).

${ }^{77}$ M. C. Buck, "Hotham, John (d. 1337)," in Oxford Dictionary of National Biography (Oxford University Press, 2004-), accessed 29 June 2015, doi:10.1093/ref:odnb/13851.

${ }^{78}$ William Betham, The Baronetage of England, vol. 1 (London, 1801), 243-44; Collier, "Lowthorpe," 35. 
William of Auvergne. He also would have owned the standard canon law texts in which the Tree of Affinity commonly appears. The involvement of clerical advisors is often proposed as an explanation for the design of artworks with particularly rich religious references, such as the elaborate Percy tomb (made ca. 1340) at Beverley Minister (Yorkshire, E.R.). ${ }^{79}$ Beat Brenk suggested that this third role should be thought of as a "concepteur": an individual whose creativity and intellect shaped the more innovative, creative and nuanced aspects of an artwork. ${ }^{80}$ Jill Caskey, however, questioned the tripartite configuration of artistic agency (patron-artist-advisor), arguing that this is a model derived from the Renaissance for which there is very little documentary evidence in the Middle Ages. ${ }^{81}$ Rigid distinctions between thought,

${ }^{79}$ Saul, "Patronage and Design," 328-29. See also Nicholas Dawton, "The Percy Tomb at Beverley Minster: The Style of the Sculpture," in Studies in Medieval Sculpture, ed. F. H. Thompson (London: Society of Antiquaries, 1983), 122-50, at 124.

${ }^{80}$ Beat Brenk, “Le texte et l'image dans la Vie des Saints au Moyen Age: rôle du concepteur et rôle du peintre," in Texte et Image: actes du colloque international de Chantilly, 13 au 15 octobre 1982 (Paris: Les Belles Lettres, 1984), 31-39. Discussed in Jill Caskey, "Medieval Patronage and its Potentialities," in Patronage, Power and Agency in Medieval Art, ed. Colum Hourihane (University Park, PA: Pennsylvania State University Press, 2013), 3-30, at 14.

${ }^{81}$ Caskey, "Medieval Patronage," 4, 14; eadem, "Whodunnit? Patronage, the Canon, and the Problematics of Agency in Romanesque and Gothic Art," in A Companion to Medieval Art, ed. Conrad Rudolph (Oxford: Blackwell, 2006), 193-212, at 196-99. See also Holly Flora, "Patronage," in Studies in Iconography Special Issue: Medieval Art History Today-Critical Terms, ed. Nina Rowe, 33 (2012), 207-18. 
financing and labor do not accord with surviving contracts and accounts, which instead reveal that a significant degree of negotiation and amendment could take place before and even during the making of a tomb. ${ }^{82}$ The reference to John de Hotham offers a potential source for the theological and legal models for the Lowthorpe tomb, but in the absence of further evidence it is important not to stretch this connection too far: the Bishop's possible role in the innovative design at Lowthorpe remains tantalizingly obscure.

\section{THE PURPOSE OF INVENTION}

SO far this article has considered the inventiveness of the Lowthorpe tomb in terms of its conception. I will now turn from a pre- to a post-natal perspective, considering the function of its novel design in the context of the collegiate foundation at Lowthorpe. As discussed above, invention and commemoration are often treated as opposing concepts in the literature on medieval tombs, which emphasizes a preference for conservative designs among patrons who saw an adherence to artistic tradition as a means of proclaiming the continuity of their lineage. By creating a tomb of striking novelty, the 'agents' at Lowthorpe broke with this pattern. This prompts us to question why, in this instance, innovation appears to have been prized over tradition.

${ }^{82}$ Saul, "Patronage and Design," 320-21. See, for example, the monument to Richard II, whose production far exceeded the original cost and time-frame, and which features pointillé decoration not included in the original contract (Philip Lindley, "Absolutism and Regal Image in Ricardian Sculpture," in The Regal Image of Richard II and the Wilton Diptych, ed. Dillian Gordon, Lisa Monnas and Caroline Elam (London: Harvey Miller, 1997), 69, 291n32). 
The liturgical context of the Lowthorpe memorial may help to explain its unusual imagery. In charters recording the foundation of Lowthorpe college in 1333, John de Heslerton sets out the composition and character of his new establishment in great detail. There were to be six perpetual chantries: the chantry of the Trinity; the chantry of St Mary; the chantry of the Archbishop (for the current archbishop of York, his predecessors and successors, and the late Edward II); the chantry of the Chapter (for the dean and canons of the church of York, living and dead, and for William de Ros, first Lord Ros); the chantry of the Founder and the chantry of the Patron (both of which were dedicated to "Sir John de Heslerton, Margery his wife, their children, heirs, fathers and mothers, the living and dead, and for John de Hothum [sic], bishop of Ely"). ${ }^{83}$ Each was to be served by its own priest, who would bear the title of the chantry. In addition, the college would be staffed by a rector and three clerks; all the clerics were to live in common in a house within the manse of the rectory. They were required to follow an extensive liturgical programme: every day the canons were to say the Commendation and Office of the Dead, High Mass, and the Divine Offices (matins and vespers at least on ferial days, and all the canonical hours on Sundays and double feast days). These charters reveal that John was concerned with the appearance of the liturgy as well as its content: he lays out detailed instructions regarding the canons' clothing and prescribes each his own seat in the choir, "according to the order of his chantry." Above all, John was keen to ensure the Heslerton family was placed at the heart of these observances. Regardless of which chantry they served, the priests were required at every mass to say suitable collects for, and make special remembrance of, John, Margery and their family.

${ }^{83}$ Calendar of Patent Rolls: Edward III, 2: 427. 
The Lowthorpe monument was closely associated with this liturgical programme. Although the tomb is now found in the south-west corner of the nave, it was originally located in the chancel. ${ }^{84}$ The remains of brass indents reveal that this area was used as a mausoleum in the later fourteenth and fifteenth centuries: these include a memorial to George Salvayn (d. 1417) and his wife, as well as a fragment of what must have been one of the largest brasses in England (dated to the 1370s). ${ }^{85}$ These remnants hint at how much has been lost from the medieval church at Lowthorpe. The monument would originally have been surrounded by stained glass, wall paintings, devotional statues and liturgical furnishings, all of which would have enhanced and complemented the meanings communicated by the tomb. ${ }^{86}$ The carved folds of the funeral pall covering the effigies of John and Margery continue over the sides of the stone slab, indicating that the monument was designed to be seen in the round (Fig. 3). The most likely position for the memorial would be in the center of the

\footnotetext{
${ }^{84}$ Allison, "Parishes: Lowthorpe," 277; Collier, "Lowthorpe," 41.

${ }^{85}$ Sally Badham, "Monumental Brasses: The Development of the York Workshops," in Medieval Art and Architecture in the East Riding of Yorkshire, British
} Archaeological Association Conference Transactions 9, ed. Christopher Wilson (London: British Archaeological Association, 1989), 180; Gittos and Gittos, "East Riding Sepulchral Monuments,” 101 and 107 n. 43; John C. Page-Philips, “A Discovery at Lowthorpe, Yorks.," Transactions of the Monumental Brass Society, 9 (1954): 126-28.

${ }^{86}$ For an account of the relationship between a fourteenth-century monument and its architectural/artistic surroundings see Julian Luxford, “The Hastings Brass at Elsing: A Contextual Analysis," Transactions of the Monumental Brass Society 18, no. 3 (2011): 193-211. 
choir before the high altar, a prestigious location often selected for the tombs of founders. ${ }^{87}$ This would have positioned the Lowthorpe tomb at the heart of the college's commemorative programme, allowing John and Margery to be physically present in the place where prayers were said for their souls. Founders of chantries often prescribed prayers such as the De Profundis to be said at the site of their tomb. For instance, the chantry regulations of Lady Elizabeth de Montacute (d. 1354) stipulate that after her demise the prior and canons of St Frideswide in Oxford should make her tomb the focus for a daily Office of the Dead, accompanied by a special prayer for her soul. ${ }^{88}$ Indeed, the innovative design of the Lowthorpe monument becomes more comprehensible when one considers the nature of its audience. Access to the chancel would have been largely restricted to the ten clerics employed at the

${ }^{87}$ For example, the brass memorial to John, third Baron Cobham (d. 1408) showing the effigy holding an image of the college he founded is situated in the center of the chancel directly before the altar platform (Saul, English Church Monuments, 126). ${ }^{88}$ The prayers that Lady Montacute prescribed at her tomb are distinct from the daily Mass celebrated for her soul, which was said at the adjacent altar in the Chapel of the Virgin Mary (Anne M. Morganstern, Gothic Tombs of Kinship in France, the Low Countries and England, (University Park, PA: Pennsylvania State University Press, 2000), 3, pl. 1.) For further examples of prayers prescribed at the site of the tomb, see Julian Luxford, "The Collegiate Church as Mausoleum," in The Late Medieval English College and its Context, ed. Clive Burgess and Martin Heale (Woodbridge: York Medieval Press, 2008), 110- 39, at 115-16; Saul, English Church Monuments, 128. 
college, who were obliged to spend many hours in liturgical observance. ${ }^{89}$ It is notable that the charters for Lowthorpe college specifically instruct all the priests to congregate together in the chancel to say the Commendation and Office of the Dead, ensuring that the tomb would be seen by every member of the college as they made intercessions for the Heslertons' souls. ${ }^{90}$ These priests were educated viewers who would have been conversant in the monument's theological references and familiar with the Heslerton family. ${ }^{91}$ The complexity of the tomb's design would reward informed, intense and prayerful looking.

When read in tandem, there are potential correspondences between the design of the Lowthorpe monument and beneficiaries mentioned in the college charters. John and Margery are represented through the recumbent effigies. The five shields near the couple's feet could represent the five beneficiaries named in the college charters (John de Hotham, William de Ros II, Edward II, the archbishop of York, and the dean

${ }^{89}$ The main exception to this being the children and heirs of John and Margery, as discussed below.

${ }^{90}$ Calendar of Patent Rolls: Edward III, 2: 427.

${ }^{91}$ For example, Robert de Heslerton, rector of Lowthorpe church from 1329 until his death in 1331, possessed a Magister degree from the University of Cambridge. See Alfred B. Emden, A Biographical Register of the University of Cambridge to 1500, (Cambridge: Cambridge University Press, 1963), 301; Robinson, Register of William Melton, 172 above and n. 290; "Notes of James Torre, 1690-94," fol. 231r. For the uncertain relationship between Robert and Sir John see note 98 below. 
and chapter of York), and may originally have been painted with their heraldry. ${ }^{92}$ The "children and heirs" of the founders may be shown through the heads sprouting from the branches of the tree. A document of 1333 relating to the settlement of a disagreement over the advowson of Lowthorpe church records that this privilege should remain in the possession of "John de Heslarton, chivaler, and Margery his wife" during their lifetimes, before passing to their five sons and two daughters: Thomas, Walter, John, Simon, Nicholas, Agnes and Margery (Fig. 15). ${ }^{93}$ If the fragmentary head at L2 originally represented a layman, the (non-tonsured) heads on the monument would thus correspond to the number and sex of the couple's children. In Gothic Tombs of Kinship Ann Morganstern argued that certain tombs made in conjunction with chantries were designed as mnemonic devices, the miniature figures of relatives on the tomb-chest acting as visual reminders of the souls for whom the canons were to pray. ${ }^{94}$ She cites a number of examples from fourteenth-century England, including the chantry of Elizabeth de Montacute, founded in 1348, the beneficiaries of which included the lady's parents, two husbands, ten children by her first husband, and two ecclesiastics from Lincoln cathedral: a canon, Simon Islip, and

\footnotetext{
${ }^{92}$ Although no traces of paint are now visible, the five shields at the east end of the monument are large enough to have contained painted heraldry, measuring $8-9 \mathrm{~cm}$ in length and $7.5-8 \mathrm{~cm}$ at their widest point.

${ }^{93}$ W. Paley Baildon, ed., Feet of Fines for the County of York, from 1327-1347, (Leeds: Yorkshire Archaeological Society, 1910), 60.

${ }^{94}$ Morganstern, Tombs of Kinship, 4. See also eadem, “Tomb as Prompter for the Chantry: Four Examples from Late Medieval England," in Memory and the Medieval Tomb, ed. Elizabeth V. del Alamo and Carol S. Pendergast (Aldershot: Ashgate, 2000), 81-97, at 81-82.
} 
the bishop, John Gynwell. ${ }^{95}$ Since the status and gender of the ten small figures in niches on long sides of Elizabeth's tomb chest correspond to those of her children (including her son Simon de Montacute, John de Hotham's successor as bishop of Ely), Morganstern argued that they should be understood as "mnemonic devices" for the priests celebrating Mass at the site of her tomb: "an abbreviated reference to the chantry that she established." 96

The relationship between the Lowthorpe memorial and the prayers of the chantry priests, however, needs to be set against the wider commemorative programme of the college. Morganstern is right to draw attention to the connections between chantries and the design of funerary monuments, but her argument that priests used images or heraldry on tombs as mnemonic prompts is problematic. It is far more likely that the names of those for whom prayers were to be said would have been written down in a book or commemorative table set up on the altar. Even these written lists must have been largely redundant, as the priests would have soon memorized the names (the only unique element of the canon of the mass for chantries) through frequent repetition. Instead of interpreting isolated elements of the Lowthorpe tomb as visual cues for the named beneficiaries of the chantries, the innovative design of the monument is better understood in its totality as a symbol for the foundation of the college. Rather than merely prompt a list of names, the design of the memorial sought to encourage more intense and prayerful intercession from the college priests by reminding them of the relationships on which their institution depended. Considered in its commemorative context, the inventiveness of the monument takes on a practical function. A treatise on memory attributed to the

\footnotetext{
${ }^{95}$ Morganstern, Tombs of Kinship, 3.

${ }^{96}$ Ibid, 3, 107-08.
} 
English theologian and mathematician Thomas Bradwardine, completed soon after 1333, stresses the need for images that were "wondrous and intense," because such things are "impressed in the memory more deeply and are better retained." 97 The unusual and striking tree on the Lowthorpe memorial "impressed" the purpose of the college foundation upon the memories of the chantry priests, visualizing the hope of salvation for the founders and their family.

The six tonsured heads may also be related to the monument's liturgical context. It has previously been assumed that all thirteen heads represent the children of the deceased couple. ${ }^{98}$ This seems a logical conclusion since the heads blossom from a tree that has its roots in the recumbent effigies of husband and wife: they are literally the couple's 'offspring.' However, the probable identification of the effigies as John and Margery de Heslerton creates difficulties with this interpretation. As mentioned above, the record of a legal settlement from 1333 notes that at this date John and Margery had only five surviving sons and two daughters. ${ }^{99}$ The same seven heirs are repeatedly listed in documents from the later fourteenth and early fifteenth

97 “Qualitas vero sit mirabilis et intensa, quia talia in memoria imprimuntur profundius et melius retinentur.” (Mary Carruthers, “Thomas Bradwardine, 'De memoria artificiale adquirenda," Journal of Medieval Latin, 2 (1992): 25-43, at 36, lines 50-51). See also eadem, Book of Memory, 141, 362-63.

${ }^{98}$ Allison, "Parishes: Lowthorpe,” 277; Collier, "Lowthorpe," 41; Gittos and Gittos, “East Riding Sepulchral Monuments," 99; Oosterwijk, "Food for Worms," 61-62; Pevsner and Neave, York and the East Riding, 606; Saul, English Church Monuments, 136.

${ }^{99}$ Baildon, Feet of Fines, 60. 
centuries. ${ }^{100}$ There is no record that any of John and Margery's children took holy orders; since we know that the two eldest sons were married, only three of the offspring at most could have been priests (Fig. 15). It is also doubtful that the additional heads represent children who died in infancy: while deceased infants could be depicted as fully-grown adults on medieval monuments (as seen on the memorial to Edward III at Westminster Abbey), there is no precedent for them to be represented as tonsured clerics. ${ }^{101}$

A possible identity for the tonsured heads is suggested through comparisons with other monuments featuring miniature clerics. These figures appear on a number of memorials from the first half of the fourteenth century, the majority located in northern England. ${ }^{102}$ At Birdsall, only twenty miles north-east of Lowthorpe, a female

${ }^{100}$ Records relating to John and Margery's children are listed in Collier, "Lowthorpe," 35-37. There is a lone reference in the register of Archbishop Melton to a "M. Robert de Heslarton, priest, son of Sir John de Heslarton, knight" (dated 21 May 1329), but Robert is not mentioned in the other contemporary documents listing the children of John and Margery. He could have been an illegitimate son, or alternatively the child of John's younger brother, another Robert (Robinson, Register of William Melton, 172).

${ }^{101}$ As Oosterwijk has pointed out, the depiction of deceased infants as adults reflects the medieval tradition that all mankind would ultimately assume the perfect age of Christ, between 30 and 33 (Oosterwijk, "Swithe Feire Graue," 181-83). For the tomb of Edward III, see Mark Duffy, Royal Tombs of Medieval England (Stroud: Tempus Publishing, 2003), 146-51, figs. 61-63.

102 James Cameron, "The Harington Tomb at Cartmel Priory: Making, Agency and Audience," (master's thesis, Courtauld Institute of Art, 2011), 24-26. See, for 
effigy is flanked by four armored knights and two priests in long robes: a combination of lay and ecclesiastical figures that echoes the memorial to John and Margery (Fig. 16). ${ }^{103}$ All the figures at Birdsall hold books, except for one of the priests who grasps the end of a scroll. ${ }^{104}$ The memorial to Sir John Harington and Joan Dacre at Cartmel Priory (Cumbria), made in ca. 1340, also depicts the bodies of the deceased surrounded by clerics, in this case thirteen Austin canons identified through their long robes, gowns and scapular (Fig. 17). ${ }^{105}$ James Cameron suggested that these clerical figures, some holding open books and others placing their hand on the shoulder of the figure in front, were intended as a reminder to the Austin canons of their commemorative responsibilities, the duty to pray for the Haringtons' souls thus "sealed" in stone. ${ }^{106}$ A similar function has been attributed to the clerics on the monument to Bishop Henry Burghersh (d. 1340), positioned at the boundary of his

example, the effigy of Brian Fitzalan at Bedale (Yorkshire, N.R.), dating from ca. 1325- ca. 1330, which has two small hooded figures holding books at his feet (Park, “Burials and Monuments," 90-91; Cameron, "Harington Tomb," 25). The motif of praying figures at the feet of the effigy achieved wider popularity in the fifteenth century, as seen in the effigy of Rahere at the priory church of St Bartholomew the Great (London), as well as that of William of Wykeham at Winchester Cathedral (Hants.).

${ }^{103}$ Cameron, "Harington Tomb," 25; Pevsner and Neave, York and the East Riding, 326.

${ }^{104}$ Cameron, "Harington Tomb," 25.

105 Ibid, 24.

${ }^{106} \mathrm{Ibid}, 28$. An additional 16 canons are depicted around the base of the tomb. 
chantry chapel in Lincoln cathedral (Fig. 18). ${ }^{107}$ The north side of the tomb chest (facing the chantry) is carved with five ogee-arched niches, each featuring a pair of clerics sitting either side of a lectern with an open book (Fig. 19). Ten small shields have been placed above the arches, six of which refer to lords mentioned in the chantry ordinances. ${ }^{108}$ The chantry priests would have seen these clerical figures every time they entered the chapel, a sculpted echo of themselves engaged in the Divine Offices. As well as reminding the priests of their liturgical duties, the monument also emphasized their connection with the Burghersh family. The Bishop's memorial was made as a pair with that of his father, Sir Robert Burghersh (d. 1306), its tomb chest filled with miniature figures of his sister's children and their spouses. ${ }^{109}$ These two monuments adjoin one another to form a continuous frieze running from the shrine to the east wall of the retrochoir, thereby juxtaposing the chantry priests with miniature figures of the Burghersh family (Figs. 18 and 19). The recurring theme in these memorials is the connection between the clerical figures and prayers for the deceased, indicated by the figures' open books and reinforced by the position of the Harington and Burghersh monuments within a chantry chapel. When considered alongside these near-contemporary monuments, it thus seems possible that the six tonsured heads on the Lowthorpe memorial were meant to signify the six chantry canons at Lowthorpe college.

${ }^{107}$ For the Burghersh tombs and chantry chapel, see Morganstern, Tombs of Kinship, 108-16.

${ }^{108}$ Morganstern, Tombs of Kinship, 111-12 (figs. 69-70), 186-87; Saul, English

Church Monuments, 125.

${ }^{109}$ Morganstern, Tombs of Kinship, 111-12, 188-89. 
If this is the case, the relationship between the canons and the founders is pictured with startling and unusual intimacy. The canons would be represented as John and Margery's 'offspring,' blossoming from the same tree as their biological children (Fig. 1). Whereas the monuments at Lincoln Cathedral and Birdsall divide lay and ecclesiastical figures into two separate groups, the Lowthorpe tomb is unique in its lack of distinction between family and priests: tonsured and non-tonsured heads are distributed among the branches of the tree without any discernable pattern (Fig. 4). This seems extraordinary from a modern perspective, but there are reasons why John and Margery may have wanted these two groups represented together in the context of their collegiate foundation. Both represented John and Margery's legacy after death, and both were sustained through the couple's lands and assets. ${ }^{110}$ As descendants of the founders and inheritors of the advowson, John and Margery's offspring would have been accorded the honor of sitting in the chancel alongside the college priests, children and canons thus surrounding the effigies of the deceased in an arrangement similar to their depiction on the monument itself. ${ }^{111}$ Just like the

${ }^{110}$ In at least one case, a chantry priest at Lowthorpe college may also have been a kinsman of Margery. A priest named "Thomas de Lowthorpe" served as a canon in the $3^{\text {rd }}$ chantry (1349-63) and then in the second chantry (1364-65), before becoming rector of the college (1363-72) (N. A. H. Lawrence, ed., Fasti Parochiales, vol. 3, Deanery of Dickering (Wakefield: Yorkshire Archaeological Society, 1966), 104-05). ${ }^{111}$ Ecclesiastical statutes from the $13^{\text {th }}$ century exempt the holder of the advowson from the general ban on laity sitting in the chancel during Mass (F. M. Powicke and C. R. Cheney, Councils and Synods: With Other Documents Relating to the English Church, vol. 2, 1205-1313, (Oxford: Clarendon Press, 1964), 275, 297, 433, 1009 $10)$. 
chantry canons, these children would have been expected to pray for John and Margery. Medieval sermons stress the special responsibility of children to care for the souls of their deceased parents in Purgatory. A chapter on care for the dead in the Speculum Laicorum, a collection of preaching exempla popular in the fourteenth and fifteenth centuries, includes the story of a son completing a penance on behalf of his recently-deceased mother, who later appeared to pronounce him "blessed... among all good sons." ${ }^{112}$ Descendants took their commemorative responsibilities seriously; there are numerous examples of offspring commissioning memorials for their parents and purchasing intercessions for their souls. ${ }^{113}$ By representing children and chantry canons as branches growing from the same tree, the Lowthorpe memorial would have reminded the priests of their child-like connection to the founders and the children of their priest-like duty to pray for John and Margery in Purgatory; its innovative design thus promoted the "bond of charity" of which Aquinas writes as fundamental to the relationship between the living and the dead. ${ }^{114}$

${ }^{112}$ J. Th. Welter, ed., Le Speculum laicorum: édition d'une collection d'exempla, composée en Angleterre à la fin du XIIIe siècle, Thesaurus Exemplorum 5 (Paris: A. Picard, 1914), ii-iii, 38.

${ }^{113}$ See Clive Burgess, “'Longing to be prayed for': Death and Commemoration in an English Parish in the Later Middle Ages," in The Place of the Dead in Late Medieval and Early Modern Europe, ed. Bruce Gordon and Peter Marshall (Cambridge:

Cambridge University Press, 2000), 44-66, at 53; Daniell, Death and Burial, 18; Saul, English Church Monuments, 109-10, 121, 130.

114 Thomas Aquinas, Summa Theologica, $3^{\text {rd }}$ part, qu. 71, art. 2. See also Binski, Gothic Wonder, 185. 
CONCLUSION

UNDOCUMENTED, damaged, its design unique amongst surviving late-medieval artworks, the Lowthorpe tomb presents numerous challenges to traditional arthistorical analysis. Given its apparent lack of influence on later memorials, it would be easy to dismiss the tomb as a mere artistic oddity, a failed experiment in a remote Yorkshire church. Yet probing beyond the surface of its strangeness, the monument offers valuable insights into the mechanisms of artistic invention in fourteenthcentury England. This innovation seems to have been the response to a specific intellectual, artistic and religious context: the collaboration of lay patrons, sculptors and ecclesiastics in the foundation of an ambitious commemorative institution. The tomb's striking and complex design would have enhanced its function as a focal point for remembrance, its polyvalent arboreal imagery conjuring associations of pedigree, intercession, patronage and mortality. The miniature heads sprouting from the couple's bodies hint at the flexibility of the concept of family in the fourteenth century, seemingly representing college priests alongside biological children just as the Tree of Jesse combined Christ's biological and spiritual ancestors. At Lowthorpe invention and commemoration seem to have been closely connected: the tomb's novel design expressed the complex web of familial, institutional and liturgical relationships within the college. Addressing the issue of innovation directly offers new and nuanced insights into artistic oddities such as Lowthorpe, as well as a deeper understanding of the processes, agents and purposes of invention in medieval art. 